International Journal of Advanced Academic Research | ISSN: 2488-9849

Vol. 7, Issue 5 (May, 2021)| www.ijaar.org

Journal DOI: www.doi.org/10.46654/ij.24889849

Article DOI: www.doi.org/10.46654/ij.24889849.e7518

\title{
Effect of Seed Priming Methods on the Germination of Detarium microcarpum
}

\author{
${ }^{1 \& 2}$ Abdulrahman A., ${ }^{2}$ Atiku M., ${ }^{2}$ Ambursa A.S., ${ }^{2}$ Umar, I., ${ }^{1}$ Muhammed, M., \\ ${ }^{1}$ Muhammad, A.G., ${ }^{1}$ Almustapha, F., ${ }^{1}$ Dogo, A.A. and ${ }^{1}$ Mainasara, H. \\ 1. College of Agriculture and Animal Science, Bakura, Zamfara state \\ 2. Kebbi State University of Science and Technology, Aliero, Kebbi state \\ Corresponding author: aasarki@gmail.com
}

\begin{abstract}
This study was carried out at Kebbi State University of Science and Technology, Aliero, Kebbi State, to determine the effect of seed priming methods on the germination of Detarium microcarpum. The study was carried out in the Forestry Laboratory of the Faculty of Agriculture. The effectiveness of nine (9) different seed priming methods was assessed, control inclusive. Treatment 1 (TRT1) seeds were soaked in tap water for 48 hours, Treatment 2 (TRT2) seeds were mechanically scarified opposite to microphyle, treatment 3, 4, and 5 (TRT3, TRT4, TRT5) seeds were immersed in $\mathrm{H}_{2} \mathrm{SO}_{4}$ for 5, 10 and 15 minutes respectively, treatment 6, 7 and 8 (TRT6, TRT7 and TRT8) seeds were soaked in hot water $\left(100^{\circ} \mathrm{C}\right)$ for 5, 10 and 15 minutes respectively and untreated seeds (CNTRL). Completely Randomized Design with three (3) replications was used. The data obtained were analyzed using one-way Analysis of Variance (ANOVA).The result revealed that seeds of D. microcarpum subjected to TRT2, TRT4, TRT5 and TRT8 recorded with highest Final Germination Percentage (FGP 100\%) and was found to differ significantly $(P<0.05)$ with other treatment and CNTRL recorded the lowest FGP $(60 \%)$.Thus, TRT2 was significantly $(P<0.05)$ enhanced the seed and germination rate of $D$. microcarpum with the highest FGP (100\%), lowest MGT (6.67), highest GRI (15.05), highest GE (12.01), lower FDG (5.67) with maximum GI value (900). Based on the result, pre-treatment of T. indica seeds with $\mathrm{H}_{2} \mathrm{SO}_{4}$ is recommended for effective germination.
\end{abstract}

Keywords: Detarium microcarpum, Seed priming, microphyle, germination 


\section{INTRODUCTION}

The importance of indigenous tree species for rural people is often underestimated. This is due to a lack of knowledge of the current uses of these trees (Akinnifesi et al., 2008). One of the major problems people face in the villages is a severe decline in tree density, due to human exploitation and uncontrolled bush burning, and rampant grazing by livestock and wildlife.

Despite the role of indigenous trees in food security, economic development, and environmental protection, there is inadequate research into germination, planting, and regeneration of indigenous woody species in Africa; and most of the work to date has been skewed towards exotic tree species. Consequently, there is an urgent need for research to improve both new and existing methods for the propagation and regeneration of indigenous tree species.

Different techniques of breaking seed dormancy to enhance germination rate and increase the germination process have been suggested by many authors (Azad et al., 2010). These include physical scarification of the seed coat by nicking, piercing with needles and knives, and/or using abrasion paper (Schmidt 2000). Methods such as cold water soaking can also be used to overcome physical seed dormancy (Sabongari, 2003). However, the breaking of seed dormancy varies from species to species. The propagation of most tropical tree species, however, is constrained by recalcitrant seed germination as a result of dormancy (Nwoboshi, 1982). The degree of dormancy makes it difficult for seeds to germinate evenly and adequately. Therefore, it is very important to determine which method and conditions are suitable for each plant species.

There is, therefore an urgent need for identifying efficient nursery management practices that will enhance their overall early nursery establishment as well as field performance at an affordable cost. This research is set to find out how seed treatment and moisture could bring about improvement in the growth and performance of the initial development of some selected indigenous trees found in the Savannah ecosystem. Although the study will be conducted in Aliero, the findings would apply to other regions with similar geo-climatic characteristics.

\section{Detarium microcarpum}

Detarium microcarpum belongs to the family Fabaceae (Bernard et al., 2019). It is a perennial woody plant indigenous to the semi-arid regions of Sub Saharan Africa which occur chiefly in West Africa, Central African Republic, (Oibiokpa et al., 2014). Propagation may be vegetative from seed (Kouyate and van Damme, 2006). It can grow up to $15 \mathrm{~m}$ tall and can reach $25 \mathrm{~m}$ in some areas (Von-meydell, 1986). It flowers during the rainy season (July to September), it bears fruit from September - January, the tree shades it leaves and produces new leaves in March (Kouyate and van Damme, 2006).

D. microcarpum grow well in a wide variety of soils including degraded and rocky areas with an annual rainfall of about 600-1000 mm (Abreu et al., 1999). Although it is usually found in fallow lands and wild bushes, it is sometimes reserved on farmlands for soil improvement, fuelwood, food and medicinal purposes (Oibiokpa et al., 2014). According to FAO (1995), D. microcarpum is a leguminous tree species that improves soil fertility when retained on farmlands through 
nitrogen fixation and leaf litter decomposition. The edible fruits of D. microcarpum are consumed by humans and wild animals in regions where the species is found (Akpata and Miachi, 2001). The fruit pulp is rich in minerals and essential vitamins such as vitamin C, E, B2, and folic acid which serve as a major food supplement during the dry season (Oibiokpa et al., 2014). These nutritional properties highlight the potential contribution of D. microcarpum to food security in Africa (Bernard, et al 2019). The fruits are equally sold in local markets and contribute to economic empowerment in rural communities (Akpata and Miachi, 2001).

Moreover, D. microcarpum is used in traditional medicine for the treatment of various ailments (Abreu et al., 1998). It also serves as a major fuelwood species with charcoal produced from the wood delivering about $1968 \mathrm{KJ} / \mathrm{kg}$ of caloric power (Kabore et al., 2005) and ranked among the most preferred fuelwood species in its natural growing areas (Sawadogo, 2007).

The multipurpose uses have resulted in overexploitation of the species to local extinction in some areas (Kabore, 2005) mainly due to the high dependence on wild plant sources with little attention on the domestication of the species. However, effective domestication will require knowledge on regeneration and other aspects of plant biology (Bohra et al., 2018).

\section{MATERIALS AND METHODS}

\section{Study Area}

The study was carried out at Kebbi State University of Science and Technology, Aliero. The study site lies on latitude $12^{\circ} 18^{\prime} 22^{\prime \prime} \mathrm{N}$ and Longitude $4^{\circ} 29^{\prime} 35^{\prime \prime} \mathrm{E}$ which covers an area of about $350 \mathrm{~km}^{2}$ (Olajuyigbeet al., 2012). Aliero is inhabited by the artisanal community with a special interest in onion and pepper farming. The area is dominated by two distinctive seasons: the wet season and the dry season with a mean annual rainfall of about $800 \mathrm{~mm}$ and temperatures of about $26^{\circ} \mathrm{C}$. Although, the temperature can go down to about $21^{\circ} \mathrm{C}$ during the harmattan and up to $40^{\circ} \mathrm{C}$ between April and June (Mukhtar, 2016). Suleiman, et al., (2016) highlighted that the area possessed two important cultivated lands namely: dryland (arid - prolong dryness) and fadama (floodplains - significant alluvial clay particles). The vegetation of the area is characterized by a few annual grasses, shrubs, and scattered trees (Suleiman, 2016) which are threatened by the inhabitants as a result of over-exploitation without replacement (Bello and Gada, 2015).

\section{Experimental Materials}

Two hundred and seventy (270) viable seeds of D. microcarpum were obtained. The average weight of the seeds was measured and recorded. Germination assessment consists of twenty seven (27) observation plots (Petri dishes) and each contained ten (10) viable seeds.

\section{Experimental Procedures}

\section{Seed collection and viability test}

The seed of D. microcarpum was obtained from the forestry and fisheries lab. of KSUST Aliero. Before the germination experiment, a seed viability test was carried out using floatation methods. 
Journal DOI: www.doi.org/10.46654/ij.24889849

Article DOI: $\underline{\text { ww.doi.org/10.46654/ij.24889849.e7518 }}$

The seeds of all the tree species undergo the floatation method separately. Seeds of each species were soaked into a beaker containing water and observed for ten (10) minutes to identify the viable seeds. The floatation method is the fastest way of testing seeds viability, which is based on the observation that empty or nonviable seeds float while viable seeds sink or settle down to the bottom of the container (Bello and Gada, 2015).

\section{Germination Assessment:}

Seeds were subjected to four pre-treatment methods with the untreated seeds as control. The pretreatment methods are;

(i) Seeds were soaked in $98 \%$ sulphuric acid concentration for 5, 10, and $15 \mathrm{~min}$

(ii) Seeds were mechanically scarified with the sandpaper opposite to micropile;

(iii) Seeds were soaked in cold water 48 hours

(iv) Seeds were soaked in boiled water $\left(100^{\circ} \mathrm{C}\right)$ for 5,10 and 15 minutes

(v) Control (untreated seeds)

Each treatment combination had 10 seeds, making a total of 270 seeds for the experiment. The pre-treated seeds were sown in a germination dish (GD) moistened with a paper towel and covered with its lid. The germination dish was arranged in a Completely Randomized Design (CRD) with 10 seeds per GD. Each treatment combination was replicated three (3) times.

\begin{tabular}{|c|c|}
\hline Pre-germination treatment & Number of seeds treated and sown \\
\hline Coldwater soaked for 48 hours (TRT1) & 30 \\
\hline Mechanical Scarification (TRT2) & 30 \\
\hline Conc. H2SO4 for 5 mins (TRT3) & 30 \\
\hline Conc. H2SO4 for 10 mins (TRT4) & 30 \\
\hline Conc. H2SO4 for 15 mins (TRT5) & 30 \\
\hline Hot water $\left(100^{\circ} \mathrm{C}\right)$ for 5 mins (TRT6) & 30 \\
\hline Hot water $\left(100^{\circ} \mathrm{C}\right)$ for $10 \mathrm{mins}(\mathrm{TRT} 7)$ & 30 \\
\hline Hot water $\left(100^{\circ} \mathrm{C}\right)$ for $15 \mathrm{mins}$ (TRT8) & 30 \\
\hline Untreated seeds (CNTRL) & 30 \\
\hline
\end{tabular}

Table 1: Treatment combination with number of treated seed

\section{Data Collection}

Germination parameters were determined daily (Ajayi and Fakorede, 2000) for thirty days. The seed was considered germinated when the tip of the radical grown out of the seed coat. Several seeds that emerged were recorded daily from the day of the first germination to the end of the germination period (4th week after sowing). Seven (7) different germination parameters were assessed. Data collected on the germination of seeds were used to calculate the followings:

1. Final germination percentage (FGP).

2. Mean germination time (MGT) 
Journal DOI: www.doi.org/10.46654/ij.24889849

3. Coefficient of the velocity of germination (CVG.

4. Germination rate index (GRI)

5. Germination index (GI).

6. Time spread of germination (TSG)

7. Germination Energy (GE).

The methodology of calculations of parameters 1, 2, 4, $6 \& 7$ followed Kader (2005), and 5 followed Ranal et al. (2009).

\section{Data analysis}

The data collected were subjected to one-way analysis of variance (ANOVA) and the means were separated at $\mathrm{P} \leq 0.05$ using Duncan's Multiple Range Test (DMRT). All statistical analyses were done using SPSS statistical package 20.0 version.

\section{RESULTS}

\section{Effect of seed pre-treatment on mean germination parameters of Detarium microcarpum}

Table 2: The effects of seed pre-treatment on mean germination parameters of Detarium microcarpum

\begin{tabular}{llllllllll}
\hline TREATMENT & FGP & MGT & GI & CVG & GRI & GE & FDG & LDG & TSG \\
\hline TRT1 & $86.67^{\mathrm{ab}}$ & $15.7^{\mathrm{bcd}}$ & $596.67^{\mathrm{cd}}$ & $6.53^{\mathrm{cd}}$ & $5.64^{\mathrm{d}}$ & $3.77^{\mathrm{d}}$ & 6.53 & 23 & 13.67 \\
TRT2 & $100^{\mathrm{a}}$ & $6.67^{\mathrm{a}}$ & $900^{\mathrm{a}}$ & $15.05^{\mathrm{a}}$ & $15.05^{\mathrm{a}}$ & $12.01^{\mathrm{a}}$ & 5.67 & 8.33 & 2.67 \\
TRT3 & $96.67^{\mathrm{ab}}$ & $12.95^{\mathrm{abc}}$ & $856.67^{\mathrm{a}}$ & $7.95^{\mathrm{bc}}$ & $7.75^{\mathrm{c}}$ & $6.43^{\mathrm{c}}$ & 11.33 & 16.33 & 5.33 \\
TRT4 & $100^{\mathrm{a}}$ & $9.87^{\mathrm{ab}}$ & $837.67^{\mathrm{ab}}$ & $10.18^{\mathrm{ab}}$ & $10.18^{\mathrm{b}}$ & $8.12^{\mathrm{b}}$ & 8.00 & 12.33 & 4.33 \\
TRT5 & $100^{\mathrm{a}}$ & $7.8^{\mathrm{b}}$ & $820^{\mathrm{ab}}$ & $12.82^{\mathrm{a}}$ & $12.82^{\mathrm{a}}$ & $10.37^{\mathrm{a}}$ & 6.33 & 9.67 & 3.33 \\
TRT6 & $83.33^{\mathrm{cd}}$ & $18.35^{\mathrm{c}}$ & $653.33^{\mathrm{c}}$ & $5.46^{\mathrm{cde}}$ & $4.55^{\mathrm{d}}$ & $3.63^{\mathrm{d}}$ & 12.33 & 23 & 14.37 \\
TRT7 & $90^{\mathrm{ab}}$ & $16.25^{\mathrm{ab}}$ & $703.53^{\mathrm{bc}}$ & $6.15^{\mathrm{cde}}$ & $5.49^{\mathrm{d}}$ & $3.99^{\mathrm{d}}$ & 8.67 & 22.67 & 13.33 \\
TRT8 & $100^{\mathrm{a}}$ & $7.53^{\mathrm{a}}$ & $840.2^{\mathrm{a}}$ & $12.71^{\mathrm{a}}$ & 12.71 & $9.67^{\mathrm{a}}$ & 6.33 & 10.34 & 4.01 \\
CNTRL & $60^{\mathrm{d}}$ & $21.6^{\mathrm{d}}$ & $506.67^{\mathrm{d}}$ & $4.65^{\mathrm{de}}$ & $2.93^{\mathrm{d}}$ & $2.55^{\mathrm{d}}$ & 17.00 & 23.67 & 6.67 \\
\hline *means followed by the same letter (superscript) are statistically same at 5\% level of probability. Key: Final \\
Germination Percentage (FGP), Germination rate index (GRI), Coefficient of Velocity of Germination (CVG), \\
Germination energy (GE), and Germination Index should have higher value and lowest values in Germination Mean \\
Time (GMT), First Germination Day (FGD), Last day of Germination (LDG) and Time Spread of Germination \\
(TSG).
\end{tabular}

In D. microcarpum (Table 2$)$, the highest FGP $(100 \%)$ was significantly $(\mathrm{P}<0.05)$ attained from four (4) treatments (TRT2, TRT4, TRT5 \& TRT8) but there is a significant difference $(\mathrm{P}<0.05)$ in CVG, GI, GRI, GE, and MGT. The lowest MGT (6.67) was recorded from TRT2 and the highest MGT (21.6) was obtained from CNTRL. The highest GI was obtained from TRT3 (900) 
Journal DOI: www.doi.org/10.46654/ij.24889849

Article DOI: www.doi.org/10.46654/ij.24889849.e7518

followed by TRT3 (856.67) and the lowest GI (506.67) was recorded from CNTRL. The highest CVG (15.05) was recorded from TRT2 followed by TRT5 (12.82) and the lowest was from CNTRL (4.65). Highest GRI (15.05) was recorded from TRT2 followed by TRT5 (12.82) and the lowest GRI was obtained from CNTRL. Highest GE (12.01) was recorded from TRT2 and the lowest GE (2.55) was obtained from CNTRL. The highest TSG was obtained from TRT6 (14.37) followed by TRT1 (13.67) and the lowest TSG was obtained TRT2 (2.67). TRT2 significantly $(\mathrm{P}<0.05)$ recorded with highest FGP reduced MGT with a lower value of 6.67 days and highest GRI (15.05), highest GE (12.01), lower FDG (5.67) with maximum GI value (900) among treatment recorded with $100 \%$ FGP.

\section{DISCUSSION}

\section{Effect of seed pre-treatment on mean germination parameters of Detarium microcarpum}

Mechanical scarification (TRT2) significantly $(\mathrm{P}<0.05)$ improved germination compared with the control. These show the effectiveness of mechanical scarification in the breaking of seed coat dormancy, which prevents the seed from taking up water. This was in support of Ambursa et al. (2019) findings which recorded the highest FGP (100\%) and lowest FDG in mechanically scarified D. microcarpum seeds within 4 DAS. Mayer and Poljakoff-Mayber (1989) reported that hard-coated seeds become permeable to water when the seed coat is broken or punctured by mechanical abrasion or chemical treatment. So also Okunola, et al. (2019), revealed that mechanical scarification of the seeds of $P$. biglobosa is effective in breaking seed coat dormancy and improving seedling vigor, which can enhance the domestication and cultivation of these valuable seeds in the environment.

Acid scarifications in (TRT3, TRT4, and TRT5) were also recorded with the highest FGPs which is significantly $(\mathrm{P}<0.05)$ higher compare to Control $(60 \%)$, this corroborated with Mohammad and Amusa (2003) on the superiority of conc. $\mathrm{H}_{2} \mathrm{SO}_{4}$ compared with other tested treatments in $T$. indica seeds. This finding is in agreement with Dachung and Verinumbe (2006) that acid treatment of seeds removed the waxy layer of seed coat by the chemical composition of seed coat like that similar to breakdown process occurring during the microbial attack. Similarly, Ambursa et al (2019) proved the effectiveness of Hot water in breaking the dormancy of the Detarium microcarpum. The increased exposure regime of D. microcarpum seeds in $\mathrm{H}_{2} \mathrm{SO}_{4}$ considerably increased GI, CVG, GRI, GE, and decreased MGT and TSG, this was supported by Awodola (1994) who reported germination increases when the immersion time increases. This is also similar to the report by Duguma et al (1998) that germination percentage increased with longer treatment of acid treatment in Leucaena leucoephala seeds.

The results also revealed that soaking $D$. microcarpum seeds in boiling water for some minutes was significant $(\mathrm{P}<0.05)$ in breaking physical dormancy, with increasing rate germination by 83.33- 100\%, compared to control (60\%), this is also similar to the Ambursa et al (2019) findings who reported highest FGP (100\%) lower FDG (6) in hot water treatment as compared to control. This result is also consistent with McDonald and Omoruyi (2003) who reported the highest germination $(70 \%)$ in Dialium guineense seed soaked in boiling water $\left(100^{\circ} \mathrm{C}\right)$ for 5 minutes. Similar results of induced germination have been obtained in Sesbania rostrata and 
Journal DOI: www.doi.org/10.46654/ij.24889849

Article DOI: www.doi.org/10.46654/ij.24889849.e7518

Sesbania sesban (Shinde et al, 1998) the result can also be associated with the findings of Aleiro (2004) who concluded that $98 \%$ of conc. $\mathrm{H}_{2} \mathrm{SO}_{4}$ gave the highest FGP with lower MGT for Parkiabiglobosa seeds. The result did not agree with the work of MacDonald and Conrad (2015) who recorded poor germination on seed treated with hot water on $T$. indica.

Immersion in Coldwater for 48 hours (TRT1) also significantly $(\mathrm{P}<0.05 \%)$ difference in all the germination indices compared to control. These findings are also similar to the Bernard et al (2019) trials, which recorded the emergence of Detarium microcarpum seeds within eight (8) days of sowing after soaking the seeds in cold water for 48 hours. This could be the ability of cold water to enhance seed coat permeability by enabling gaseous exchange and enzymatic hydrolysis to transform the embryo into a seedling (Olatunji, et al. 2013). The finding is in agreement with Sankhyan et al (2008), which concluded the effectiveness of cold water (24 hours) and Conc. $\mathrm{H}_{2} \mathrm{SO}_{4}$ in promoting the germination of Bani oak (Quercus glauca).

There was a significant $(\mathrm{P}<0.05)$ difference in FGP between seeds soaked in normal water (TRT1) at room temperature for $48 \mathrm{hrs}$ and the control. These results are in agreement with studies conducted using seeds of different tree species (Fredrick et al., 2016). Similarly, it is in agreement with Kundu et al (1998), who observed increased germination in Alstonia scholaris when subjected to cold water soaking for 24hrs. This entails that different species have varying rates at which their seed coat is permeable to water and gases (Owonubi et al. 2005).

\section{CONCLUSION}

The studies were carried out to determine the best method of breaking seeds dormancy that is effective, and affordable, for optimum and uniform germination. Detarium microcarpum seed possessed hard seed coat and it requires scarification to start germinating, based on these findings mechanical scarification is shown to be the best and most effective way to break seed dormancy. 
Journal DOI: www.doi.org/10.46654/ij.24889849

Article DOI: $\underline{\text { ww.doi.org/10.46654/ij.24889849.e7518 }}$

\section{REFERENCES}

Abreu, P.M., Martins, E.S., Kayser, O., Bindseil, K.U., Siems, K., Seemann, A., and Frevert.J. (1999).Anti-microbial, anti-tumor, and anti-leishmania screening of medicinal plants from Guinea-Bissau. Phytomedicine 6(3):187-195.

Ajayi, S.A. and Fakorede, M.A.B. (2000).Physiological Maturity Effects on Seed Quality. Seedling vigor and mature plant characteristics of maize in a tropical environment. Seed Sci. Technol. 28: 301-309

Akinnifesi, F.K., Sileshi, G., Ajayi, O.C., Chirwa, P.W., Kwesiga, F.R. and Harawa, R. (2008). Contributions of agroforestry research and development to the livelihood of smallholder farmers in Southern Africa: 2. Fruit, medicinal, fuelwood, and fodder tree systems. Agric J. 3:76-88.

Akpata MI, Miachi OE (2001) Proximate composition and selected functional properties of Detarium microcarpum. Plant Foods for Human Nutrition 56(4):297-302.

Aliero, B.L. (2004). Effects of sulphuric acid, mechanical scarification, and wet heat treatments on germination of seeds of African locust bean tree, Parkiabiglobosa. African Journal of Biotechnology, 3 (3):179-181

Ambursa S. A., Muhammad, A., Tijjani A., Sanda H. Y. andHamidat, M. M. (2019). Effect of Seed Priming Methods on Germination of Sweet Dattock (Detarium microcarpum) and Indian Jujube (Ziziphusmauritiana) in Sudan Savanna Ecological Zone of Nigeria, Asian Journal of Advances in Agricultural Research 10(2): 1-11. ISSN: 2456-8864

Awodola, A.M (1994). Aspects of germination in seeds of African locust bean tree Parkiabiglobosa Don. J Tropical Forest Resource. 10: 82-91.

Azad, S., Manik, M.R., Hasan, S., and Matin A. (2011). Effect of different pre-sowing treatments on seed germination percentage and growth performance of Acacia auriculiformis.Journal of Forestry Research, 22: 183. doi: 10.1007/s11676- 011-0147-y.

Bello, A.G. and Gada Z.Y. (2015). Germination and early growth assessment of Tamarindus indica L in Sokoto State, Nigeria Hindawi Publishing CorporationInternational. Journal of Forestry Research. Article ID 634108, 5 pages

Bernard N. B., Latif, I. N., Adnan, S., Hamza, I. and William J. A. (2015).Effect of seed pretreatment and its duration on germination of Detarium microcarpum (Guill. and Perr.).. African Journal of Environmental Science and Technology.13(8): 317-323 ISSN:19960786

Bohra P, Waman AA, Basantia D, Devi HL, and Reang E (2018) Domestication and conservation efforts in Haematocarpusvalidus (Miers.) Bakh. F. ex Forman: an underutilized fruit species and natural colorant. Current Science 115(6):1098-1105. 
Journal DOI: www.doi.org/10.46654/ij.24889849

Article DOI: www.doi.org/10.46654/ij.24889849.e7518

Duguma, B., Kang, B.T., and Okali, D.U. (1998). Factors affecting germination of Leuceanaleucophala seed. Science and Technology 16:489-500.

Fredrick C, Muthuri C, Ngamau K and Sinclair F. (2016).Provenance and pretreatment effect on seed germination of six provenances of Faidherbiaalbida(Delile) A. Chev. Agroforestry Systems, doi:10.1007/s10457-016-9974-3.

Food and Agriculture Organisation FAO (1995).State of the World's Forests - 1995. Rome, Italy: Food and Agriculture Organization of the United Nations.

Kabore C (2005). Aménagement des forêts au Sahel - Point survingtannées de pratiques au Burkina Faso. Ouagadougou, Burkina Faso: Ministère de l’Environnementet de l’Eau.

Kader, M. A. (2005). A Comparison of Seed Germination Calculation Formulae and the Associated Interpretation of Resulting Data. Journal \& Proceedings of the Royal Society of New South Wales, Vol. 138, p. 65-75, ISSN 0035-9173/05/020065

Kouyate AM, van Damme P (2006). Detarium microcarpum Guill. \& Perr. In: Schmelzer, G.H. \&Gurib-Fakim, A. (Eds.) Medicinal plants 1 [CD-Rom]. Wageningen, Netherlands: PROTA Foundation 11(1)

Kundu, M., Sharma, P., Kachari, J. and Sett, R. (1998).Effect of pretreatment on germination and seedling vigour in Alstoniascholaris.Seed Research, 25(1): 16-18.

MacDonald, I. and Conrad, A.O. (2005).Effect of various pre-treatments on the seedling growth performance of Tamarindusindica L. Journal of plant biosystems 135 (2)165-168.

MacDonald I and Omoruyi, O. (2003).Effect of seed pre-treatment on germination of two surface types of Dialiumguineense.SeedTechnology, 25(1):41-44.

Mayer. A.M. and Poljakoff-Mayber, A. (1989).The Germination of Seeds. Fourth edition, Pergamon Press.71-111.

Muhammad, S. and Amusa, N.A. (2003).Effects of sulphuric acid and hot water treatments on seed germination of tamarind (Tamarindus indica L). African Journal of Biotechnology, 2 (9): 276-279.

Mukhtar, R.B. (2016): Influence of light intensity on early growth of Adansoniadigitata (L.). Research Journal of Recent Sciences.5(12): 5-9.

Nwoboshi, L.C. (1982). Indices of macronutrient deficiency in Khayasenegelensis. Journal Communication in Soil Science Plant Analysis. 13(8): 667-682

Oibiokpa I.F., Adoga, I.G., Saidu, A.N. and Shittu, O.K. (2014). Nutritional composition of Detarium microcarpum fruit. African Journal of Food Science 8(6):342-350. 
Journal DOI: www.doi.org/10.46654/ij.24889849

Olajuyigbe, S.O., Jimoh, S.O., Adegeye, A.O and Mukhtar, R.B. (2013).Drought stress on early growth of Diospyros mespiliformis Hochst ex A. Rich in Jega, Northern Nigeria. Nigerian Journal of Ecology 12(1):71-76.

Olajuyigbe, S.O., Jimoh, S.O., Adegeye, A.O. and Mukhtar, R.B. (2012).Drought stress on early growth of Diospyros mespiliformis (Hochst ex. A.) in Jega, Northern Nigeria. Nigerian Journal of Ecology, 12(1): 71-76.

Olatunji, D.J., Maku, O. and Odumefun, O.P. (2013).The effect of pre-treatments on the germination and early seedlings growth of Acacia auriculiformis Cunn. Ex. Benth. African Journal of Plant Science, 7(8):325-330.

Owonubi, J.J., Otegbeye, G.O., and Nwokedi, C. (2005). Development of pre-germination technique for Azadirachta indica: a preliminary investigation. In: Sustainable Forest Management in Nigeria: Lessons and Prospects. Proceedings of the 30th Annual Conference of the Forestry Association of Nigeria, held in Kaduna, Kaduna State.7-11th November 2005. p 29-38.

Ranal, M. A., De Santana G. D., Ferreira W.R. and Mendes-Rodrigues C. (2009).Calculating germination measurements and organizing spreadsheets. Revista Brasil. Bot., 32(.4), 849-855,

Sankhyan, H.P., Sehgal, R.N. and Rajan, B. (2008). Influence of seed size and pre-sowing treatments on the germinability attributes of Quercus glauca Thunb. (Bani oak) in Himachal Pradesh. Annals of Forestry, 16(2): 295- 300.

Shinde, A.K., Riwale, A.P., Bhave, S.G. and Birari, S.P. (1998).Effect of different seed treatments on germination of Sesbania species. Annals of Agricultural Research, 19(2): 208-209.

Suleiman, U. (2016). Surface soil factors and soil Characteristics in geophysical milieu of Kebbi State. Eurasian Journal of soil science. 5(3):209-220

Suleiman, U., Noma, S.S. and Kudiri, A.M. (2016) Dynamic surface soil components of land and vegetation types in Kebbi State Nigeria. Eurasian Journal of soil science. 5(2):113-120

Von maydell, H, J. (1990).Trees and Shrubs of the Sahel, Their Characteristics and Uses. Weakershein: Verlag Josef Magraf Scientific Books 